\title{
SISTEM INFORMASI PENUNJANG KEPUTUSAN PENENTUAN GURU TERBAIK PADA SEKOLAH SMP ISLAM AL HIKMAH DENGAN METODE ANALYTICAL HIERARCHY PROCESS (AHP)
}

\author{
Nugroho Bagus Wibowo ${ }^{1)}$, Dian Anubhakti ${ }^{2)}$ \\ ${ }^{1}$ Sistem Informasi, Fakultas Teknologi Informasi, Universitas Budi Luhur \\ ${ }^{1,2} \mathrm{JI}$. Raya Ciledug, Petukangan Utara, Kebayoran Lama, Jakarta Selatan 12260 \\ E-mail: nbw1996indo@gmail.com ${ }^{1)}$, dian.anubhakti@budiluhur.ac.id ${ }^{22}$
}

\begin{abstract}
Abstrak
Yayasan SMP Islam Al-Hikmah hati adalah Yayasan yang bergerak di penyelengaraan Pendidikan, telah berdiri sejak tahun 1994,Jl.Kemajuan no50. 55,Petukangan Selatan,Kec.Pesanggrahan,Kota Jakarta Selatan Prov.D.K.I.Jakarta , salah satunya dengan melakukan penentuan guru terbaik di setiap angkatan. Permasalahan yang terjadi pada penentuan guru terbaik di SMP Islam Al Hikmah yaitu Wakabid Kurikulum Banyaknya guru yang ada sulit untuk melakukan keputusan pemilihan guru berprestasi secara tepat serta membutuhkan waktu yang lama dalam perhitungannya. Penelitian ini bertujuan untuk membuat suatu Decision Support System (DSS) dengan metode Analytical Hierarchy Process (AHP) dan untuk mempersingkat dalam penentuan guru secara tepat, tanpa membutuhkan waktu yang lama dalam perhitungan. Selain itu sistem dapat diakses dimana saja dan kapan saja. Penentuan guru berprestasi ditentukan dari menjumlahkan hasil kriteria-kriteria yang tertera dalam bobot yang telah ditentukan. Hasil yang ada akan dirangking sesuai dengan perhitungan yang ada pada metode AHP Aplikasi dibangun menggunakan Bahasa Pemprograman: PHP, MySQL front. Kesimpulan: Dengan adanya sistem penunjang keputusan ini, dapat membantu pihak Tata Usaha dan Kepala Sekolah pada SMP Islam Al-Hikmah dalam menentukan guru terbaik dengan metode laporan cetak hasil perankingan.
\end{abstract}

Kata kunci: Penentuan Guru Terbaik, Sistem Penunjang Keputusan

\section{PENDAHULUAN}

Yayasan SMP Islam Al-Hikmah hati adalah Yayasan yang bergerak di penyelengaraan Pendidikan, telah berdiri sejak tahun 1994. Dengan di dasari idesialis yang tertinggi dengan ikut serta mengambil bagian dalam mencerdaskan anak-anak Bangsa dengan biaya yang terjangkau serta memberikan pendidikan yang berkualitas Sejak itu Yayasan Islam Al Hikmah mengemban amanah membantu menumbuhkan, mengembangkan, membentuk, dan mengarahkan anak didik menjadi hamba Allah yang shaleh; yang lurus aqidahnya, mulia akhlaqnya, cerdas akalnya, sehat dan kuat fisiknya, dekat dan cinta kepada Al-Quran. Kemudian pada juli 2006.

Sementara itu, adanya kesulitan di SMP Islam Al Hikmah untuk menentukan keputusan guru terbaik dikarenakan masih dilakukan secara lambat, tanpa menggunakan data yang valid untuk membandingkan setiap kriteria yang ada, dan sering terjadinya tidak teridentifikasi data lalu dalam penentuan, oleh karena itu diperlukan sistem yang user friendly dalam pengoperasian untuk menentukan keputusan guru terbaik di SMP Islam Al Hikmah.. Dan dalam penelitian ini, saya beracuan pada penelitian sebelumnya, yang terjadi pada 5 tahun belakangan ini, dengan metode Analytical Hierarchy Process (AHP). Pemilihan Guru Berprestasi Pada Smkn 1 Sutera Kabupaten Pesisir yang menggunakan kriteria pendukung sebagai berikut: kehadiran, penilaian siswa, prilaku, prestasi kerja, pengalaman kerja.

Tujuan Penelitian menghasilakn suatu sistem penunjang keputusan untuk menentukan guru terbaik dengan mengukan metode (AHP).

\section{STUDI PUSTAKA}

\subsection{Definisi Sistem Penunjang Keputusan}

Sistem penunjang keputusan atau Decision Support System (DSS) adalah sebuah sistem yang dimaksudkan untuk mendukung para pengambil keputusan manajerial dalam situasi keputusan semi terstruktur.

Menurut (A. Paramita, F. A. Mustika, and N. Farkhatin, 2017) Guru adalah pendidik profesional yang memiliki tugas, fungsi, dan peran penting dalam mendidik bangsa. Agar fungsi dan tugas yang melekat pada posisi fungsional guru dilakukan sesuai dengan aturan yang berlaku, perlu untuk menilai kinerja guru yang menjamin proses pembelajaran yang berkualitas. Menentukan kinerja guru dapat mendorong peningkatan kualitas pendidikan dan meningkatkan motivasi dan profesionalisme guru dalam melakukan tugas. Kepala sekolah membuat 15 kriteria untuk menentukan guru terbaik, yaitu: kehadiran, aturan disiplin, tanggung jawab dan produktivitas, interaksi 
sosial, motivasi dan pengembangan diri, inovatif, responsif dan inisiatif, fleksibilitas dalam tugastugas lain, komunikasi, kerja tim, kejujuran, ramah dan sopan, pakaian estetika, efektif dalam menggunakan gadget, kebersihan dan kerapian kelas. Untuk menentukan kinerja guru, maka satu keputusan yang dapat dilakukan menggunakan Analytical Hierarchy Process (AHP).[3]

Menurut (R. Artika, 2013 )penulis merancang sistem pendukung keputusan penilaian kinerja pegawai menggunakan Analitycal Hierarchy Process (AHP) di RSUD Serang. Metode Analitycal Hierarchy Process (AHP) adalah suatu model pengambilan keputusan yang komprehensif dan terstruktur [4]

Menurut (O'Brien \& Marakas, 2014) "Sistem pendukung keputusan merupakan sebuah sistem informasi yang menggunakan model keputusan, sebuah database dan sebuah wawasan dari pembuat keputusan dalam sebuah proses pemodelan yang ad hoc dan interaktif untuk mencapai sebuah keputusan yang spesifik oleh seorang pembuat keputusan yang spesifik.”[5]

\subsection{Use Case Diagram}

Use Case Diagram digunakan untuk menjabarkan proses dalam sistem berjalan yang di gambarkan dengan diagram-diagram menurut pandangan orang yang berada diluar sistem atau actor[5].

\subsection{ERD}

Pengertian ERD adalah perancangan basis data yang paling inti pada sebuah sistem yang akan digunakan[6].

\subsection{Tools yang digunakan}

a. Definisi Sublime Text 3

Menurut Eric Haughee (2013) "Sublime text adalah aplikasi editor untuk kode dan teks yang dapat berjalan di berbagai platform operating system dengan menggunakan teknologi Phyton API.

\section{b. XAMPP}

XAMPP perangkat lunak bebas, yang mendukung banyak sistem operasi, merupakan kompilasi dari beberapa program

$$
\text { c. MySQL }
$$

MySQL merupakan database engine atau server database yang mendukung bahasa database pencarian $S Q L$

\section{d. Microsoft Visio}

Menurut Helmers (2013), Microsoft Visio adalah aplikasi utama untuk membuat semua diagram bisnis, mulai dari flowchart, network diagram, dan organization charts, untuk membuat denah dan brainstorming diagram

$$
\text { e. draw.io }
$$

draw.io adalah sebuah aplikasi open source untuk membuat aplikasi yang berbasis diagram, dan aplikasi yang paling banyak dipakai browser-based, oleh yang mahir dalam aplikasi diagram

f. Balsamiq Mockups

Balsamiq mockup adalah program aplikasi yang digunakan dalam pembuatan user interface sebuah aplikasi

\section{METODE PENELITIAN}

Metode Pengumpulan Data yang digunakan:

1. Observasi

Tahapan pertama ini dilakukan untuk mengambil data dengan cara memperhatikan langsung proses penentuan guru terbaik pada SMP Islam Al Hikmah sebagai masukan tugas akhir ini.

2. Wawancara

Tahapan ke 2 ini dilakukan empat mata untuk perkembangan riset ini. Pertanyaan yang diberikan mengenai kesulitan yang bersenyambungan dengan penentuan guru terbaik. Dari wawancara tersebut, untuk mengambil dokumen yang akan dipergunakan untuk pembuatan.

3. Analisa Dokumen

Selanjutnya untuk ini informasi yang di dapatkan dengan menganalisa dokumen yang telah di kerjakan selama di SMP AL Hikmah.

4. Kuesioner

Kuesioner ini merupakan perintah responden pertanyaan yang di ajukan untuk menganalisa data pada SMP Islam Al Hikmah.

5. Studi Literatur

Metode ini dilakukan dengan mengumpulkan dan membaca dokumen-dokumen sebagai referensi seperti penelitian yang tertera di perpus atau dokumen lain yang telah dipublikasi.

\section{HASIL DAN PEMBAHASAN}

\subsection{Proses Bisnis Berjalan}

Proses dimulai dari wakil kepala sekolah melakukan penilaian kinerja guru, untuk tiap tahunnya penilaian tersebut berisi aspek penilaian kinerja guru yang akan dinilai, kemudian wakil kepala sekolah merekap daftar absensi guru, setelah dilakukan rekap absensi, wakil kepala sekolah membuat laporan penilaian kinerja guru dan langsung diserahkan kepada kepala sekolah, kemudian kepala sekolah menerima laporan hasil penilaian kinerja, kepala sekolah melakukan pengumuman kepada guru, apabila kinerja guru buruk, maka guru akan dikenakan teguran bahwa kinerja buruk, apabila kinerja guru baik maka guru akan diberikan penghargaan. (Gambar 1) 


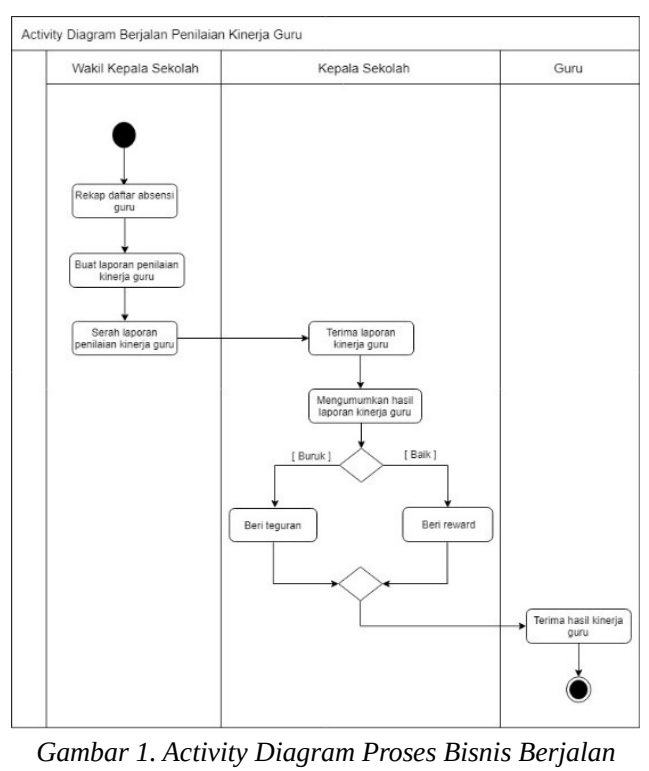

\subsection{Analisa Masalah}

Dalam menganalisa masalah pada pengambilan keputusan untuk menentukan guru terbaik yang akan dipilih, penulis menggunakan fishbone diagram atau yang sering disebut diagram Ishkawa (Gambar 2).

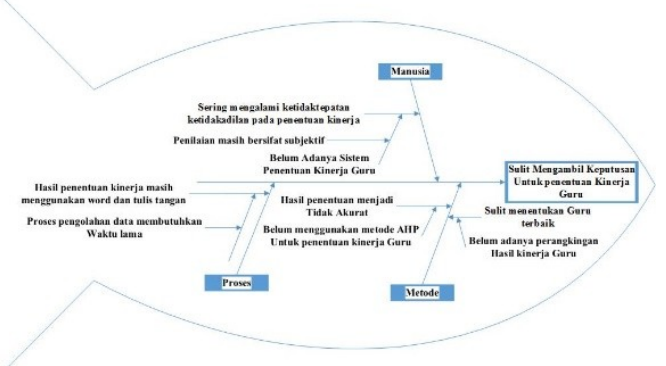

Gambar 2. Fishbone Diagram

\subsection{Identifikasi Kebutuhan}

Dari masalah yang dilihat sebelumnya, telah diidentifikasi sebagai user yang akan mengoprasikan sistem. Use Case Diagram mengartikan aktivitas untuk permintaan dari pengguna sistem.

\section{Use Case Diagram Input}

Use Case Diagram input (Gambar 3) terdiri dari aktivitas entry data guru, entry data kelas, dan entry data nilai kriteria.

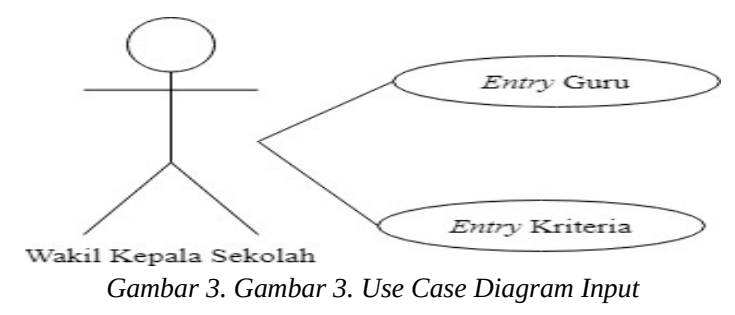

\section{Use Case Diagram Proses}

Use Case Diagram Proses (Gambar 4) terdiri dari: Proses Perbandingan Kriteria, Proses Perbandingan Alternatif, Proses Perangkingan dan Entry Hasil Keputusan.

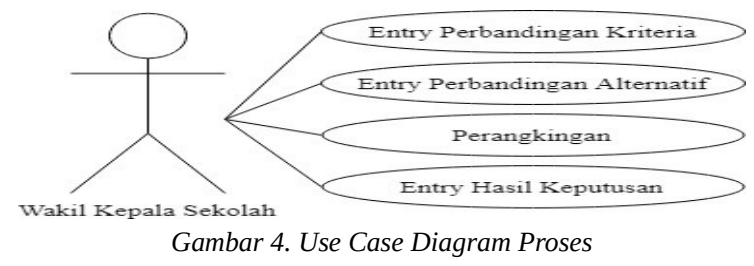

\section{Use Case Diagram Laporan}

Use Case Diagram Laporan (Gambar 5) terdiri dari, Cetak Laporan Hasil Keputusan Guru Terbaik, dan Cetak Laporan Rangking Guru.

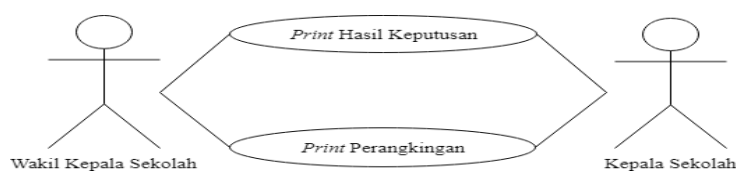

Gambar 5. Use Case Diagram Laporan

\subsection{Kriteria Dalam Penilaian Guru}

Disini terdapat beberapa kriteria yag telah di dapat dari SMP Islam Al Hikmah yaitu: Absensi, Ketertiban, Kesopanan, dan Profesional:

a. Nilai Perbandingan Kepentingan Antar Kriteria

Nilai perbandingan kepentingan antar kriteria didapat dari, kuesioner itu perintah responden pertanyaan yang di ajukan untuk menganalisa data pada SMP Islam Al Hikmah SMP Islam Al Hikmah:

1. Absensi 3 (tiga) kali lebih penting dari Ketertiban.

2. Absensi 5 (lima) kali lebih penting dari Kesopanan.

3. Absensi 7 (tujuh) kali lebih penting dari Profesional.

4. Ketertiban 6 (enam) kali lebih penting dari Kesopanan.

5. Ketertiban 4 (empat) kali lebih penting dari Profesional .

6. Kesopanan 2 (dua) kali lebih penting dari Profesional.

b. Perbandingan Kepentingan Antar Kriteria

Perbandingan kepentingan antar kriteria didapat dari, kuesioner itu perintah responden pertanyaan yang di ajukan untuk menganalisa data pada SMP Islam Al Hikmah SMP Islam Al Hikmah:

Tabel 1. Matriks Perbandingan Kepentingan Per Kriteria

\begin{tabular}{lllll}
\hline Kriteria & Absensi & Ketertiban & Kesopanan & Profesional \\
\hline Absensi & 1 & 3 & 5 & 7 \\
Ketertiban & $1 / 3$ & 1 & 6 & 4
\end{tabular}


Kesopanan 1/5 Profesional $1 / 7$ $1 / 6$ $1 / 4$ 1
$1 / 2$

Langkah-langkah dalam menentukan bobot masing-masing kriteria adalah sebagai berikut:

1) Langkah 1

Menjabarkan matriks di atas ke dalam bentuk desimal:

$$
\left[\begin{array}{llll}
1,0000 & 3,0000 & 5,0000 & 7,0000 \\
0,3333 & 1,0000 & 6,0000 & 4,0000 \\
0,2000 & 0,1667 & 1,0000 & 2,0000 \\
0,1429 & 0,2500 & 0,5000 & 1,0000
\end{array}\right]
$$

2) Langkah 2

Mengalikan matriks dengan dirinya sendiri:

$\left[\begin{array}{llll}1,0000 & 3,0000 & 5,0000 & 7,0000 \\ 0,3333 & 1,0000 & 6,0000 & 4,0000 \\ 0,2000 & 0,1667 & 1,0000 & 2,0000 \\ 0,1429 & 0,2500 & 0,5000 & 1,0000\end{array}\right]$
$\left[\begin{array}{llll}1,0000 & 3,0000 & 5,0000 & 7,0000 \\ 0,3333 & 1,0000 & 6,0000 & 4,0000 \\ 0,2000 & 0,1667 & 1,0000 & 2,0000 \\ 0,1429 & 0,2500 & 0,5000 & 1,0000\end{array}\right]$

3) Langkah 3

Hasil dari perkalian matriks:

$$
\left[\begin{array}{rrrc}
4,0002 & 8,5835 & 31,500 & 36,000 \\
2,4382 & 4,0001 & 15,6665 & 22,3331 \\
0,7414 & 1,4334 & 4,0002 & 6,0668 \\
0,4691 & 1,0121 & 3,2145 & 4,0003
\end{array}\right]
$$

4) Langkah 4

Menjumlahkan tiap-tiap baris hasil dari perkalian matriks:

$$
\left[\begin{array}{c}
80,0837 \\
44,4329 \\
12,2418 \\
8,696
\end{array}\right]
$$

5) Langkah 5

Menormalisasikan dengan membagi tiap-tiap jumlah baris pada matriks dengan total

6) Langkah 6

Menentukan bobot dari masing-masing kriteria yang diambil dari eigenvector.

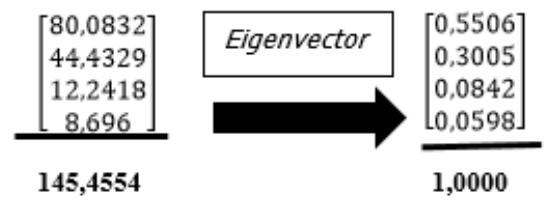

Tabel 2. Bobot Kriteria

\begin{tabular}{ll}
\hline Nama Kriteria & Bobot \\
\hline Absensi & 0,5506 \\
Ketertiban & 0,3055 \\
Kesopanan & 0,0842 \\
Profesional & 0,0598 \\
\hline
\end{tabular}

\subsection{Pengujian Metode Analyrical Hierarchy} Process (AHP)

Pengujian model AHP dilakukan dengan cara menghitung nilai Consistency Index (CI) dan nilai Consistency Ratio (CR), dengan langkah-langkah sebagai berikut:

1. Langkah1

Mengalikan nilai bilangan desimal dari setiap matriks kriteria dengan eigenvector

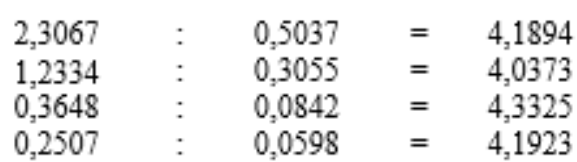

2. Langkah 2

Menghitung Consistency Vector dengan jalan menentukan nilai rata-rata dari Weighted Sum Vector. Kriteria Absensi Ketertiban Kesop Profes Eigen- Hasil anan ional vector

\begin{tabular}{lrlrrr}
\hline Absensi & 1,0000 & 3,0000 & 5,0000 & 7,0000 & $0,5506=2,3067$ \\
Ketertiban & 0.3333 & 1,0000 & 6,0000 & 4,0000 & X 0,3055 = 1,2334 \\
Kesopanan & 0,2000 & 0,1667 & 1,0000 & 2,0000 & $0,0842=0,3648$ \\
\multicolumn{2}{l}{ Profesional 0,1429 } & 0,2500 & 0,5000 & 1,0000 & $0,0598=0,2507$ \\
\hline
\end{tabular}

3. Langkah 3

Menghitung nilai rata-rata dari Consistency Vector adalah:

$$
\pi=\frac{4,1894+4,0373+4,3325+4,1923}{4}=4,2142
$$

4. Langkah 4

Menghitung nilai Consistency Index dengan menggunakan rumus:

$$
\begin{aligned}
& \mathrm{CI}=\frac{(\pi-n)}{n-1} \quad \mathrm{n}=\text { banyaknya kriteria } \\
& \mathrm{CI}=\frac{(4,2142-4)}{4-1}
\end{aligned}
$$

5. Langkah 5

Menghitung Consistency Ratio, dibutuhkan nilai RI yaitu Random Index yang didapat dari tabel Oarkridge $C R=\frac{C I}{R I}$ untuk $\mathrm{n}=4$, maka nilai $\mathrm{RI}$ adalah 0,90 .

$$
\mathrm{CR}=\frac{0,0714}{0,90}
$$

$\mathrm{CR}=0,0793$ 
Inti hitung di dapat, nilai CR kriteria penentu guru terbaik di SMP Islam Al Hikmah adalah 0,0793 .

\subsection{Hasil Analisa Alternatif}

Dapati dilihat di tabel 3 hasil perankingan guru terbaik pada SMP Islam Al Hikmah.

Tabel 3. Perangkingan

\begin{tabular}{llllll}
\hline \multicolumn{2}{l}{ Alternatif Absensi } & \multicolumn{4}{l}{ Ketertiba Kesopana Profesion Hasil } \\
& & n & n & al & Rangking \\
\hline A1 & 0,1346 & 0,3368 & 0,1473 & 0,0963 & 0,1952 \\
A2 & 0,3032 & 0,0750 & 0,1520 & 0,2540 & 0,2176 \\
A3 & 0,1874 & 0,1819 & 0,3184 & 0,2832 & 0,2025 \\
A4 & 0,1874 & 0,2309 & 0,2391 & 0,2384 & 0,2080 \\
A5 & 0,1874 & 0,1755 & 0,1432 & 0,1281 & 0,1770 \\
Bobot & 0,5506 & 0,3055 & 0,0842 & 0,0598 & \\
\hline
\end{tabular}

A1 Dra. Leni Wirza

$$
\begin{aligned}
& =\{(0,1346 \times 0,5506)+(0,3368 \times 0,3055)+( \\
& 0,1473 \times 0,0842)+(0,0963 \times 0,0598)\} \\
& =(0,0741+0,1029+0,0124+0,0058)=0,1952
\end{aligned}
$$

A2 Drs. Samudera Arya

$$
\begin{aligned}
& =\{(0,3032 \times 0,5506)+(0,0750 \times 0,3055)+ \\
& (0,1520 \times 0,0842)+(0,2540 \times 0,0598)\} \\
& =(0,1669+0,0229+0,0127+0,0151) \\
& =0,2176
\end{aligned}
$$

A3 Resinari Wulandari, S.Pd

$=\{(0,1874 \times 0,5506)+(0,1819 \times 0,3055)+$ $(0,3184 \times 0,0842)+(0,2832 \times 0,0598)\}$

$=(0,1032+0,0556+0,0268+0,0169)$

$=0,2025$

A4 Muhawallah, S.Pd

$=\{(0,1874 \times 0,5506)+(0,2309 \times 0,3055)+$ $(0,2391 \times 0,0842)+(0,2384 \times 0,0598)\}$

$=(0,1032+0,0705+0,0201+0,0142)$

$=0.2080$

A5 Azamidah, S.Kom

$=\{(0,1874 \times 0,5506)+(0,1775 \times 0,3055)+$ $(0,1432 \times 0,0842)+(0,1281 \times 0,0598)\}$

$=(0,1032+0,0542+0,0120+0,0076)$

$=0,1770$

Dapat disimpulkan bahwa penentuan guru terbaik adalah A2 yaitu Drs. Samudera Arya

Daftar urutan sebagai berikut:

A2 Ranking 1 Drs. Samudera Arya

A4 Ranking 2 Muhawallah, S.Pd

A3 Ranking 3 Resinari Wulandari, S.Pd

A1 Ranking 4 Dra. Leni Wirza

A5 Ranking 5 Azamidah, S.Kom

\subsection{Perancangan Database}

Model ini basis rancangan model ERD, seperti pada (Gambar 6) yang akan di terapkan SMP Islam Al Hikmah.

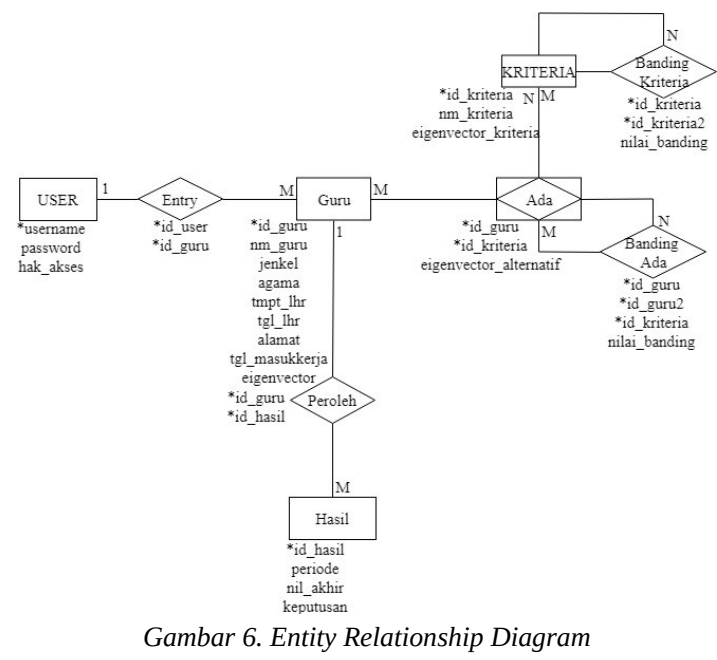

\subsection{Logical Record Structure (LRS)}

Model ini dirancang untuk keperluan pengembangan sistem penunjang keputusan. Sebuah rancangan model data disajikan dalam bentuk Entity Relationship Diagram (ERD).

Transformasi (ERD) ke Logical Record Structure (LRS)



\subsection{Rancangan Layar}

Rancangan layar pada Sistem Penunjang Keputusan Penentuan Guru Terbaik adalah sebagai berikut: (Gambar 7). 


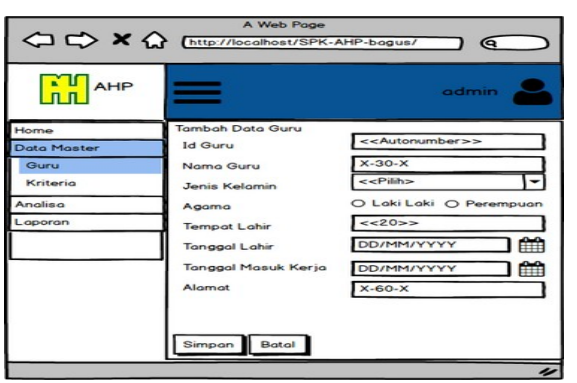

Gambar 8. Rancangan Layar Master Guru

Pada (Gambar 8) dibawah ini merupakan rancangan layar untuk pembobotan Kriteria.

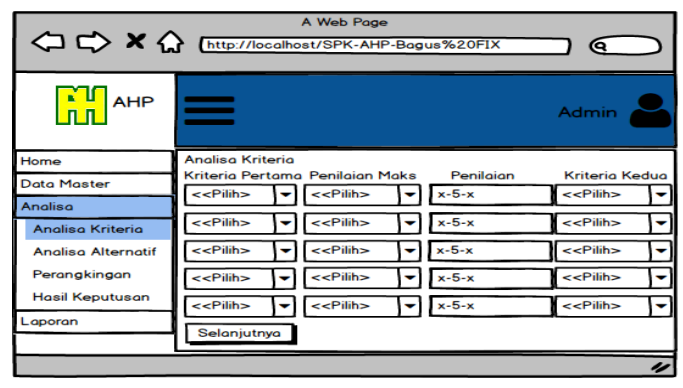

Gambar 9. Rancangan Layar Pembobotan Kriteria

Selanjutnya adalah proses penilaian alternatif User memasukkan nilai alternatif tiap guru pada kriteria (Gambar 9).

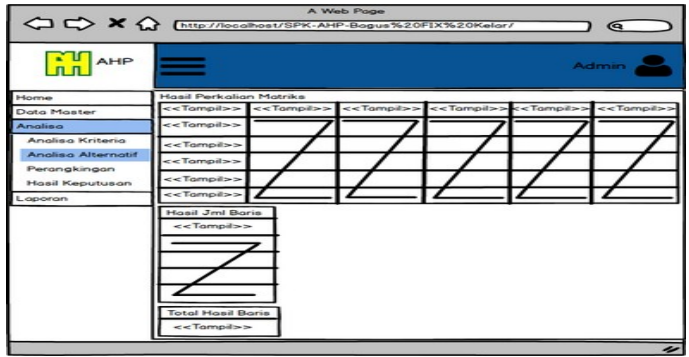

Gambar 10. Rancangan Layar Penilaian Alternatif Guru

Setelah itu dengan tampilan rancangan layar pada (Gambar 9), mengisi form lalu klik simpan untuk menyimpan data

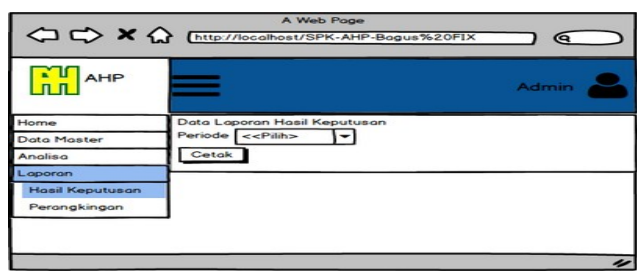

Gambar 11. Rancangan Layar Entri Hasil Keputusan

\subsection{Hasil Penelitian}

Telah sampailah di akhir dengan penentuan hasil riset di sekolah SMP Islam Al Hikmah sebagai berikut:

\begin{tabular}{lll}
\hline Alternatif & Total Nilai & Rangking \\
\hline Drs. Samudera Arya & 0,2176 & 1 \\
Muhawallah, S.Pd & 0,2080 & 2 \\
Resinari Wulandari, S.Pd & 0,2025 & 3 \\
Dra. Leni Wirza & 0,1952 & 4 \\
Azamidah,S.Kom & 0,1770 & 5 \\
\hline
\end{tabular}

\section{KESIMPULAN}

Kesimpulan yang di dapat berdasarkan analisa yang di lakukan di bab-bab sebelumnya sebagai berikut:

Dengan adanya sistem penunjang keputusan ini, dapat membantu pihak Tata Usaha dan Kepala Sekolah pada SMP Islam Al-Hikmah dalam menentukan guru terbaik dengan metode laporan cetak hasil perankingan

\section{DAFTAR PUSTAKA}

[1] A. Eko, "Sist. Pendukung Pengambilan Keputusan Penentuan Pemilihan Guru Berprestasi Pada Smkn 1 Sutera Kabupaten Pesisir Selatan Menggunakan Metod. Anal. Hierarchy Dengan Implementasi Bhs. Pemograman Php Dan Mysql”, vol. 10, no. 1, pp. 72-83, 2017.

[2] W. D. Puspitasari and D. K. Ilmi, "Sistem Pendukung Keputusan Pemilihan Dosen Berprestasi Menggunakan Metode Analytical Hierarchy Process (Ahp)," Antivirus J. Ilm. Tek. Inform., vol. 10, no. 2, pp. 56-68, 2016.

[3] A. Paramita, F. A. Mustika, and N. Farkhatin, "Aplikasi Sistem Pendukung Keputusan Guru Terbaik Berdasarkan Kinerja dengan Metode Analytical Hierarchy Process ( AHP )," vol. 03, no. 01, pp. 9-18, 2017.

[4] R. Artika, "Penerapan Analitycal Hierarchy Proccces(Ahp) Dalam Pendukung Keputusan Penilaian Kinerja Guru Pada Sd Negeri," Penerapan Anal. Hierarchy Proccces(Ahp) Dalam Pendukung Keputusan Penilai. Kinerja Guru Pada Sd Negeri, vol. IV, p. 123, 2013.

[5] O'Brien, J. A., \& Marakas, G. M. (2014). Sistem Informasi Manajemen (9 ed.). Salemba Empat

[6] R. Adrifa, R. Kurniawan, and A. Sofyan, "Perancangan Sistem Pengontrolan Stok Barang pada Blesscom Komputer Dengan Metode Economic Order Quantity (EOQ),” J. Inform., vol. 10, no. 1, pp. 39-47, 2018. 